\title{
Effect of Tax Paying Awareness, Knowledge and Understanding of Taxation Regulations and Service Quality on the Willingness to Pay Tax Mandatory Individual
}

\author{
$1^{\text {st }}$ Ratih Kumala ${ }^{1}, 2^{\text {nd }}$ Renisya Ayu ${ }^{2}$ \\ \{ratih.kumala@stiami.ac.id ${ }^{1}$, renisyanisya@gmail.com ${ }^{2}$ \} \\ Institut Ilmu Sosial Dan Manajemen Stiami ${ }^{1,2}$
}

\begin{abstract}
Tax is one of the sources of state finance, including individual taxpayers who are the government's mainstay for obtaining funds to finance state administration. For taxpayers who perform independent personal services, neither party is required to pay taxes. This phenomenon is almost attractive to ignore the factors that encourage people to pay taxes. This study will discuss the effect of taxes, knowledge and understanding of tax regulations, and service quality on tax willingness to individual taxpayers. The object of this research is individual taxpayers who work independently in Bekasi City, especially those registered at KPP Bekasi Utara and KPP Bekasi Selatan with a total sample of 100 respondents. The test used in testing the hypothesis, to ascertain whether the independent variable is partially or not on the dependent variable and to determine the effect of the independent variable on the dependent variable is simultaneously used the F test. From known research it is known that tax awareness, knowledge and understanding of regulations taxation has a significant effect on willingness to pay. Meanwhile, service quality has an effect but not significantly on willingness to pay taxes. This states that tax officers are required to provide friendly, fair and firm services to taxpayers at all times and can raise public awareness about tax tax responsibilities.
\end{abstract}

Keywords: Awareness of Paying Taxes, Knowledge and Understanding of Tax Regulations, Quality of Service, Willingness to Pay Taxes. 


\section{Introduction}

Taxes are a source of state finance, including individual taxpayers who are the government's reliance on to obtain funds to finance state implementation. For taxpayers who perform independent personal services neither party is compelled to pay taxes. They have a tax ID of their own accord. This phenomenon is considered interesting to be associated with the factors that encourage people to pay taxes, therefore this study will discuss the effect of awareness of paying taxes, knowledge and understanding of tax regulations, and service quality on the willingness to pay taxes of individual taxpayers.

The object of this research is an individual taxpayer who does independent work in Bekasi, especially registered at North Bekasi KPP and South Bekasi KPP with a sample size of 100 respondents. The $t$ test is used in hypothesis testing, to determine whether the independent variable is partially significant or not on the dependent variable and to determine the effect of the independent variable on the dependent variable simultaneously, the F test is used.

From the research that has been done, it is known that awareness of paying taxes, and knowledge and understanding of tax regulations have a significant effect on the willingness to pay taxes. Meanwhile, service quality has an effect but not significantly on the willingness to pay taxes. This states that tax officials are required to provide friendly, fair and firm services to taxpayers at all times and can foster public awareness about the responsibility of paying taxes.

\section{Methods}

The research design used in this study is a quantitative approach, namely the research used to describe the influence of taxpayer awareness, knowledge and understanding of tax regulations, quality on the willingness of taxpayers to pay taxes.

The population in this research is individual taxpayers who work independently in Bekasi City, especially in two KPP Pratama Bekasi Utara and Bekasi Selatan. Because in these two tax offices most of them do independent work, such as: workshop services, furniture shops, doctors and midwives who open their own work practices, notaries, travel services, computer and internet rentals, driving and sewing courses, and so on. other.

While the sample is part of the number and characteristics of the population (Sugiyono, 2014: 118). The sample selected in this study using the Convinience Random Sampling technique obtained by 100 respondents.

$$
\begin{aligned}
& \mathrm{n}=\frac{383.976}{(1+383.976)(0,1)^{!}} \\
& \mathrm{n}=99,973963 \\
& \mathrm{n}=100
\end{aligned}
$$

And the data collection method used in this study is a questionnaire method. While the data analysis technique used is multiple linear regression analysis techniques, namely to determine the effect of independent variables on the dependent variable. In addition, this 
research is also accompanied by a validity test, reliability test, classical assumption test, determination coefficient test, significant $\mathrm{F}$ test and partial test $(\mathrm{t}$ test).

The variables used in this study are the dependent variable (dependent) and the independent variable (independent). The dependent variable is the variable that is affected or that is the result of the existence of the independent variable.

The dependent variable in this research is Willingness to Pay Taxes (Y). Willingness to pay taxes in this study is defined as a value that is willing to be contributed by someone, which is determined by regulation, which is used to finance general state expenditures without receiving direct (contra-achievement) services (Vanessa and Hari, 2009).

The first independent variable in this research is Taxpayer Awareness (X1). Awareness of paying taxes can be defined as a situation in which someone knows, understands, and understands how to pay taxes. And awareness of paying taxes can also be interpreted as a form of moral attitude that contributes to the state and strives to obey all the regulations that have been established by the state and can be forced on taxpayers.

While the second independent variable in this study is Knowledge and Understanding of Tax Regulations (X2). Knowledge and understanding of tax regulations is the process by which taxpayers know about taxation and can apply this knowledge to pay taxes.

And the last or third independent variable in this study is Service Quality (X3). Service is a way of serving by helping care for or preparing all the needs someone needs. In simple terms, the definition of quality is a dynamic condition related to products, human services, processes, and the environment that meet or exceed the expectations of those who want them.

From the explanation above, this variable is measured using a Likert scale with the following answer scores: Score 1 (strongly disagree); score 2 (disagree), score 3 (neutral), score 4 (agree), and score 5 (strongly agree).

\section{Result And Discussions}

The data in this study were obtained from a questionnaire that has been distributed to 100 individual taxpayer respondents who are domiciled in Bekasi City, to be precise, who are registered at KPP Pratama Bekasi Utara and Bekasi Selatan. Characteristics of respondents in this study include gender, age, level of education, and length of time as taxpayers.

The validity test is obtained by testing each questionnaire. From the results of the processed data, the results of the validity test of this study indicate that the correlation value of each question item is $>0.3$, this explains that each question is valid in measuring a variable.

Reliability testing is to measure an instrument in interval consistency using Cronbach's Alpha Coeffiecient. The results of the reliability test in this study showed that Cronbach's Alpha value was $>0.6$, this means that the questions used in this study as a measuring tool were reliable.

While the results of the normality test in this study concluded that the data spreads around the diagonal line and follows the direction of the diagonal line, so the data is normally distributed so that it can be said that the regression model has met the assumption of normality. The second assumption test is the heteroscedasticity test with the Glejser test, which is a condition where the variance inequality of the residuals in the regression model occurs. A good regression model requires no heteroscedasticity problems. To detect the presence or absence of heteroscedasticity is to look at the dots pattern in the regression scatterplots. If the dots spread out in an unclear pattern above and below the 0 on the $\mathrm{Y}$ axis, 
there is no heteroscedasticity problem. The results of the heteroscedasticity test in this study indicate that in this regression equation there is no heteroscedasticity problem. This is obtained from the distribution of points that do not have a clear pattern, and the points are spread above and below the number 0 on the $\mathrm{Y}$ axis, so it can be concluded that the data in this equation model does not occur heteroscedicity symptoms. And the third assumption test is the autocorrelation test, which aims to test whether in a linear regression model there is a correlation between the confounding error in period $t$ with the error in period $t-1$ (previous). According to Ghozali (2005), a good regression model is a regression model that is free from autocorrelation. The results of the autocorrelation test of this study showed the Durbin Watson (DW) statistical value of 1.705 , it can be said that this study is free from autocorrelation problems or there is no confounding error because the DW is located between -2 to +2 which means there is no autocorrelation. And the last assumption test is the multicollinearity test in this study aimed to test whether the regression model found a correlation between the independent variables (independent). The multicollinearity test results in this study indicate that there are no independent variables that have a tolerance value less than 0.10 . The VIF test results also show the same thing, namely that none of the independent variables has a VIF of more than 10. So it can be concluded that all variables have met the tolerance threshold and the VIF value, meaning that there is no multicollinearity problem between the independent variables in the regression equation.

The results of testing the hypothesis of this study produce multiple regression which is obtained using the least squares method is $\mathrm{Y}=9.830+0.246 \mathrm{X} 1+0.202 \mathrm{X} 2+0.127 \mathrm{X} 3+\mathrm{e}$. Where the relationship between the dependent variable and the independent variable is quite strong, namely $40 \%$, while the value of R Square or the coefficient of determination is 0.161 , this value indicates that $16.1 \%$ of the variation or change in the dependent variable can be explained by variations or changes in the independent variable, and the rest is $83.9 \%$. influenced by other factors not included in this study.

As is known in the taxation system, that taxpayers are entrusted with implementing the Self Assestment System, namely by calculating, calculating, paying, self-reporting the tax owed. The amount of tax is calculated by the taxpayer himself, then pays the tax payable based on the provisions of the applicable tax laws. Lerche (2000) also argues that tax awareness is often an obstacle in the problem of collecting taxes from the public and taxpayer awareness of taxation is needed to improve taxpayer compliance.

The $t$ test (T-test) is to determine whether each independent variable affects the dependent variable. The results of the t test in this study show that the Tax Paying Awareness (X1) has a significance value of 0.041 , which means that this value is less than 0.05 , with $\mathrm{t}$ counting 2.085 and t table 1.664 or $\mathrm{t}$ count $>\mathrm{t}$ table. Based on this, it is concluded that partially the awareness variable of paying taxes has an effect on the willingness to pay taxes because the significance value is smaller than 0.05 and $t$ count $>t$ table. The results of the research for this variable are in accordance with the research conducted by Widayati and Nurlis, (2010). Which states that consciousness is an element in humans in understanding reality and how to act or respond to reality. This high awareness itself comes from none other than the motivation of the Taxpayer. If the awareness of taxpayers is high which comes from the motivation to pay taxes, the willingness to pay taxes will be high and state income from taxes will increase.

Knowledge and Understanding of Tax Regulations (X2) has a significance value of 0.031 , which means that this value is less than 0.05 , with $t$ count of 2.202 and $t$ table of 1.664 or $t$ count $>t$ table. Based on this, it is concluded that partially the variables of knowledge and understanding of tax regulations have an effect on the willingness to pay taxes because the 
significance value is smaller than 0.05 and $t$ count $>t$ table. The results showed that knowledge and understanding of tax regulations had a significant effect on the willingness to pay taxes.

Lack of knowledge and understanding of taxation is one of the causes of low willingness to pay taxes. From this research is expected to be a reference for tax officers to increase the willingness to pay taxes. One of the efforts made is to provide tax education and socialization among the public, especially those who do independent work.

Service Quality (X3) has a significance value of 0.126 , which means that this value is greater than 0.05 with $t$ count of 1.548 and $t$ table 1.664 or $t$ count $<t$ table. Based on this, it is concluded that partially the service quality variable has an effect on but not significant to the willingness to pay taxes because the significance value is greater than 0.05 and $t$ count $<t$ table.

The results of the research for this variable state that tax officials are required to provide friendly, fair, and firm services to taxpayers at all times and can foster public awareness about the responsibility of paying taxes. Taxpayers can recognize taxes from the services provided by tax officials. For this reason, tax officials must have the skills to satisfy taxpayers. The better the tax authorities service, the taxpayer will have a positive attitude towards the tax process. However, if the tax authorities service is not good, it will make taxpayers reluctant to pay taxes in accordance with applicable regulations.

The $\mathrm{F}$ test in this study is to determine whether the awareness variable of paying taxes, knowledge and understanding of tax regulations and service quality affects the willingness to pay individual taxpayers collectively, the F statistical test is used.The $\mathrm{F}$ statistical test results with the SPSS program show that $\mathrm{F}$ count of 4.666 with a significance level of 0.005 is much smaller than 0.05 , therefore this regression model can be used to predict the variables

willingness to pay taxes.

Based on the results of the $t$ test and $f$ test that have been carried out, it is known that partially the awareness variable of paying taxes has a significant effect on the willingness to pay taxes, as well as the variables of knowledge and understanding of tax regulations also have a significant effect on the willingness to pay taxes, while the quality of service has an effect but not significant to the willingness to pay taxes. Then simultaneously the three variables together have an effect on the willingness to pay taxes for individual taxpayers.

\section{Conclusion}

Based on the results of research and discussion, the following conclusions were obtained:

1. Awareness of paying taxes (X1) has a significant effect on willingness to pay taxes. This shows that the high taxpayer awareness that comes from the motivation to pay taxes, then the willingness to pay taxes will be high and state income from taxes will increase.

2. Knowledge and understanding of tax regulations (X2) has a significant effect on the willingness to pay taxes.

3. Service quality (X3) has a significant but not significant effect on willingness to pay taxes. This states that tax officials are required to provide friendly, fair, and firm services to taxpayers at all times and can foster public awareness about the responsibility of paying taxes. 


\section{Acknowledgement}

Praise and gratitude for the author, pray the presence of Allah SWT for all His gifts and Mercy so that the author can complete this scientific writing on time. With humility, the author would like to thank all those who have been involved in encouraging and assisting the author in the preparation of this scientific writing, especially to the STIAMI Institute of Social Sciences and Management. Thank you for the help and guidance of all parties, which is truly invaluable, may Allah SWT give you a better reply. thanks.

\section{References}

[1]. Aini, Anindita Nur. 2012. Faktor - faktor yang mempengaruhi kemauan untuk membayar pajak bagi wajib pajak orang pribadi yang melakukan pekerjaan bebas dikabupaten blora. Surakarta : Universitas Muhammadiyah.

[2]. Ajzen. I., 1991. The Theory of Planned Behaviour. In: Organizational Behaviour and Human DecisionProcess. Amherst, MA: Elsevier, 50: 179-211.

[3]. Anangga, Septian. 2012. Studi Empiris Pada Penggunaan Aplikasi Pajak: Integrasi Theory Of Planned Behavior dan Technolgy Acceptance Model. Skripsi. Universitas Diponegoro.

[4]. Andriana, Ateng. 2011. Analisi Atas Pengaruh Penerapan Self Assessment System Dan Kualitas Pelayanan Pajak Terhadap Kepatuhan Format Wajib Pajak di KPP Cicadas Kota Bandung. Skripsi Unikom. Bandung.

[5]. Anggraeni, Monica Dian. 2011. Pengaruh Pemanfaatan Fasilitas Perpajakan Sunset Policy Terhadap Tingkat Kepatuhan Wajib Pajak. Semarang: Universitas Diponegoro. eprints.undip.ac.id/29742/1/Skripsi008.pdf diakses tanggal 27 September tahun 2012.

[6]. Anggraeni, Intan Yuningtyas. 2013. Faktor-Faktor Yang Mempengaruhi Kepatuhan Wajib Pajak Terhadap Penerimaan Pajak Penghasilan Pada Kantor Pelayanan Pajak Pratama Semarang Tengah Satu. Diponegoro Journal of Social and Politic.

[7]. Arum, Harjanti Puspa (2012). Pengaruh Kesadaran Wajib Pajak, Pelayanan Fiskus, dan Sanksi Pajak terhadap Kepatuhan Wajib Pajak Orang Pribadi yang Melakukan Kegiatan Usaha dan Pekerjaan Bebas”. Skripsi Tidak Dipublikasikan, Fakultas Ekonomika dan Bisnis, Universitas Diponegoro.

[8]. Aryobimo, Putut dan Nur Cahyonowati. 2012. Pengaruh Persepsi Wajib Pajak tentang Kualitas Pelayanan Fiskus terhadap Kepatuhan Wajib Pajak dengan Kondisi Keuangan Wajib Pajak dan Preferensi Risiko sebagai Variabel Moderating (Studi Empiris terhadap Wajib Pajak Orang Pribadi di Kota Semarang). Jurnal Akuntansi Volume 1 No.2. Semarang: Fakultas Ekonomika dan Bisnis Universita Diponegoro.

[9]. Bambang Supomo dan Nur Indriantoro, 2002, Metodologi Penelitian Bisnis, Cetakan Kedua, Yogyakara; Penerbit BFEE UGM.

[10]. Boediono, B. 2003. Pelayanan Prima Perpajakan. Rineka Cipta: Jakarta.

[11]. Chau, Gerald and Patrick Leung. 2009. A Critical Review of Fishcer Tax Compliance Model (A Research Syntesis). Journal of Accounting and Taxation, 1(2): p 34-40.

[12]. Choong, K.F., \& Lai, M.L. 2009. Self Assessment Tax System and Compliance Complexities : Tax Practitioners Perspectives. Oxford Bussiness \& Economics Coference Program.

[13]. Devano, S dan Siti Rahayu. 2006. Perpajakan: Konsep, Teori, dan Isu, Kencana, Jakarta.

[14]. Doran, Micheal. 2009. Tax Penalties and Tax Compliance. Harvard Journal on Legislation (www.ssrn.com), 46: p 111-116.

[15]. Feld, Lars P \& Frey, Bruno S. 2002. Trust Breeds Trust : How Taxpayers are Treated Working Paper No. 98. Institute For Empiricial Research in Economics University of Zurich.

[16]. Ghozali, Imam. 2005. Aplikasi Analisis Multivariate dengan Program SPSS. Edisi 3. Semarang : Badan Penerbit Universitas Diponegoro. 
[17]. Ghozali, Imam. 2007 .Aplikasi Analisis Multi Variate Dengan Program SPSS. Semaram: Badan Penerbitan Universitas Diponegoro.

[18]. Gilbert. G. Ronald, Veloutsou Clepatra, Goode, Mark M.H. And Moutinho L. 2004. Measuring Customer Satistaction in The Fast Food Industry Cross - National Approach. The Journal of Sources Marketing, Vol 18 (5): p 371- 383.

[19]. Gunadi. 2005. Akuntansi Pajak. Jakarta : PT. Gramedia Widiasarana.

[20]. Handayani, Sapti Wuri. 2011. Faktor-faktor yang mempengaruhi Kemauan Membayar Pajak Wajib Pajak Orang Pribadi yang melakukan Pekerjaan Bebas. Purwokerto: Universitas Jenderal Soedirman.

[21]. Hardiningsih, Pancawati. 2011. Faktor-faktor yang mempengaruhi kemauan membayar pajak. Semarang : Universitas Stikubank.

[22]. Hardiningsih, Yulianawati. 2011. Faktor-Faktor Yang Mempengaruhi Kemauan Membayar Pajak. Jurnal Dinamika Keuangan dan Perbankan Vol. 3 No. 1.

[23]. Hariyati, Nunuk .2010. Pengaruh kualitas layanan terhadao kepuasan wajib pajak (studi pada pelayanan pajak pratama Purbalingga). Malang : Universitas Negeri Malang.

[24]. Heider, Fritz. 1958. The Psychology of Interpersonal Relations, New York: Wiley.

[25]. Henrik Hammar, Sverker C. Jagers, and Katarina Nordblom. 2005. Tax Evasion and the Importance of Trust. Working Paper in Economics no. 179. Swedia.gupea.ub.gu.se/bitstream/.../gunwpe0179.pdf

[26]. Isgiyarta, Tantra Ikhlas Nalendro. 2014. Factor-Faktor yang Mempengaruhi Kemauan Membayar Pajak Wajib Pajak Orang Pribadi yang Berwirausaha dengan Lingkungan sebagai Variabel Moderasi. Ejournal-s1.undip.ac.id Volume 3 No.3

[27]. Ishandoko, Mohamad Agus. 2012. Pengaruh Sanksi Perpajakan, Pelayanan Fiskus, Pemahaman Wajib Pajak dan Kesadaran Wajib Pajak terhadap Kepatuhan Wajib Pajak (Studi Kasus Pada Wajib Pajak Orang Pribadi Di KPP Pratama Bangkalan). Jurnal Fakultas Ekonomi Universitas Trunojoyo Madura.

[28]. James, S \& Nobes C. 1997. The Economics of Taxation, Priciple, Policy and Practise. Europe: Prentice Hall.

[29]. James, Simon \& Alley Clinton. 2002. Tax Compliance, Self-Assessment And Tax Administration. MPRA Paper 26906. University Library of Munich, Germany.

[30]. Jatmiko, Agus Nugroho. 2006. Pengaruh Sikap Wajib Pajak pada Pelaksanaan Sanksi Denda, Pelayanan Fiskus dan Kesadaran Perpajakan terhadap Kepatuhan Wajib Pajak (Studi Empiris Terhadap Wajib Pajak Orang Pribadi di Kota Semarang). Semarang. Universitas Diponegoro.

[31]. Juniati Putri, Kadek dan Putu Ery Setiawan. 2017. Pengaruh Kesadaran Wajib Pajak, Pengetahuan dan Pemahaman Peraturan Perpajakan, Kualitas Pelayanan, dan Sanksi Perpajakan terhadap Kepatuhan Wajib Pajak di Kantor Pelayanan Pajak Pratama Denpasar Timur. Jurnal ISSN: 23028556 E-Jurnal Akuntansi Universitas Udayana Vol.18.2. Februari (2017): 1112-1140

[32]. Lovihan siska. 2014. Pengaruh kesadaran membayar pajak, pengetahuan dan pemahaman peraturan perpajakan, dan kualitas layanan terhadap kemauan membayar pajak wajib pajak orang pribadi di Kota Tomohon. Ejournal.unsrat.ac.id Volume 5 No.1

[33]. Mujiyati dan Aris, M. Abdul. 2011. Perpajakan Kontemporer. Surakarta : Muhamadiyah University Press

[34]. Nugroho, Rahman Adi. 2012. Faktor-Faktor Yang Mempengaruhi Kemauan Untuk Membayar Pajak Dengan Kesadaran Membayar Pajak sebagai Variabel Intervening (Studi Kasus Pajak Orang Pribadi Yang Melakukan Pekerjaan bebas yang Terdaftar di KPP Pratama Semarang Satu). Diponegoro Journal Of Accounting. Vol.1 No 2.

[35]. Nurmantu, S. 2000. Dasar-dasar Perpajakan. Jakarta. Ind-Hil-Co.

[36]. Palil, Mohd. Rizal. 2005. Taxpayers Knowledge: A Descriptive Evidence on Demographic Factors in Malaysia. The Journal of Accounting. 7(1): p 11- 21.

[37]. Pemerintah Republik Indonesia. Peraturan Pemerintah Nomor 46 Tahun 2013 tentang Pajak Penghasilan atas Penghasilan Dari Usaha Yang Diterima atau Diperoleh Wajib Pajak Yang Memiliki Peredaran Usaha Tertentu, Jakarta 
[38]. Pratiwi, Agung Mas Andriani dan Putu Ery Setiwan. 2011. Pengaruh Kesadaran Wajib Pajak, Kualitas Pelayanan, Kondisi Keuangan Perusahaan, dan Presepsi tentang Sanksi Perpajakan pada Kepatuhan Wajib Pajak Reklame di Dinas Pendapatan Kota Denpasar. Jurnal ISSN2302-8556. Universitas Udayana

[39]. Probondari, Ryanni Z. 2013. Faktor-Faktor Yang Mempengaruhi Kemauan Membayar Pajak Oleh Wajib Pajak Orang Pribadi Yang Terdaftar Di Kantor Pelayanan Pajak Pratama Bintan. Artikel Ilmiah, Universitas Maritim Raja Ali Haji, Tanjungpinang.

[40]. Purwoko, Aditya Dwi. 2008. Pengaruh Pelaksanaan Self Assessment System, Kualitas Pelayanan KPP, Tingkat Pendidikan Terhadap Motivasi Wajib Pajak Memenuhi Kewajiban Pajak. Skripsi UIN. Jakarta.

[41]. Qomaria, Siti. 2008 .Analisis Pengaruh Pengetahuan Tentang Pajak dan Tingkat Pendidikan Wajib Pajak Terhadap Kesadaran Membayar Pajak. Skripsi UIN. Jakarta.

[42]. Rahmawaty dkk. 2011. Faktor-Faktor Yang Mempengaruhi Kemauan Membayar Pajak. Jurnal Telaah \& Riset Akuntansi Vol.4; $202-215$.

[43]. Rantung, Tatiana Vanessa dan Priyo Hari Adi. 2009. Dampak program sunset policy terhadap faktor-faktor yang mempengaruhi kemauan membayar pajak. Salatiga : Universitas Kristen Satya Wacana.

[44]. Resmi, Siti. 2007. Perpajakan Teori dan Kasus, Edisi 2. Jakarta : Salemba Empat.

[45]. Resmi, Siti. 2011. Perpajakan : Teori dan Kasus. Edisi 6. Jakarta : Salemba Empat.

[46]. Ryff, Carol D. 1989. Happiness is Everything, or Is It? Explorations on the Meaning of Psychological Well-Being. "Journal of Personality and Social Psychology". Vol 57:1069-1081.

[47]. Setyonugroho, Hariyadi. 2012. Faktor-Faktor yang Mempengaruhi Kemauan untuk Membayar Pajak Wajib Pajak Orang Pribadi di KPP Pratama Surabaya Tegalsari. Surabaya : Sekolah Tinggi Ilmu Ekonomi Perbanas.

[48]. Siahaan, Marihot Pahala. 2010. Hukum Pajak Elementer Konsep Dasar Perpajakan Indonesia. Yogyakarta : Graha Ilmu.

[49]. Soemitro Rochmat. 2007. Dasar-dasar Hukum Pajak dan Pajak Pendapatan; PT. Eresco, Bandung .

[50]. Sudjana, Nana. 2006. Dasar-Dasar Proses Belajar Mengajar. Sinar Baru Algensindo : Bandung.

[51]. Sugiyono .2007. Statistika Untuk Penelitian, Penerbit Alfabeta, Bandung.

[52]. Sugiyono. 2014. Metode Penelitian Kuantitatif, Kualitatif dan R\&D. Bandung: Alfabeta.

[53]. Suliari dan Kardinal. 2014. Pengaruh Pemahaman, Kualitas Pelayanan, Ketegasan Sanksi Pajak, dan Pemeriksaan Perpajakan Terhadap Kepatuhan Wajib Pajak Pada KPP Pratama Ilir Barat. www.eprints.mdp.ac.id/1120/1/67Jurnal.pdf. Diakses pada 21 November 2014.

[54]. Supadmi, Ni Luh. 2009. Meningkatkan Kepatuhan Pajak Melalui Kualitas Pelayanan. AUDI Jurnal Akuntansi dan Bisnis. Vol 2.

[55]. Umar, Husein. 2008. Metode Penelitian untuk Skripsi dan Tesis Bisnis Edisi Kedua. Jakarta: PT RajaGrafindo Persada.

[56]. Undang-undang Republik Indonesia Nomor 16 Tahun 2009 Tentang Perubahan Keempat Atas Undang undang Nomor 6 Tahun 1983 Tentang Ketentuan Umum dan Tata Cara Perpajakan.

[57]. Waluyo, 2012, Akuntansi Pajak, Edisi 4, Jakarta : Salemba Empat.

[58]. Waluyo, 2010, Perpajakan Indonesia, Edisi 7, Jakarta : Salemba Empat.

[59]. Widayanti dan Nurlis. 2010. Faktor-Faktor yang Mempengaruhi Kemauan untuk Membayar Pajak Wajib Pajak Orang Pribadi yang Melakukan Pekerjaan Bebas (Studi Kasus pada KPP Pratama Gambir Tiga). Makalah Simposium Nasional Akuntansi XIII. Purwokerto.

[60]. Widodo, Widi. 2010. Moralitas, Budaya, dan Kepatuhan Pajak. Bandung: Alfabeta. 